\title{
Identification of Hepatitis A Virus Antibody among Bangladeshi Children and their Correlation with Socioeconomic Condition
}

\author{
S Mahmud ${ }^{1}$, A S M B Karim ${ }^{2}$, J Alam ${ }^{3}$, S K Saha ${ }^{4}$, S S Ahmed ${ }^{5}$, M M Z Islam $^{6}$, \\ N K Sarker ${ }^{7}$, A S Munshi ${ }^{8}$, S Sarker ${ }^{9}$, M Afroz ${ }^{10}$, F Tasneem ${ }^{11}$
}

${ }^{1}$ Dr. Salahuddin Mahmud

Assistant Professor

Dhaka Shishu Hospital, Dhaka

${ }^{2}$ Prof. A.S.M. Bazlul Karim

Paediatric Gastroenterology \&

Nutrition, BSMMU

${ }^{3}$ Dr. Jahangir Alam

${ }^{4}$ Prof. S.K. Saha

Dept. of Microbiology,

Bangladesh Institute of Child

Health, Dhaka Shishu Hospital

${ }^{5}$ Dr. Syed Shafi Ahmed

${ }^{6}$ Dr. M.M. Ziaul Islam

7Dr. N.K. Sarker

${ }^{8}$ Dr. A.S. Munshi

9 Dr. Shaoli Sarker

${ }^{10}$ Dr. Mahenaz Afroz

Assistant Professor of Gynae, NICRH

${ }^{11}$ Dr. Farhana Tasneem MD (Paediatrics)-Final part student, BICH

\section{3, 5 Professor}

Bangladesh Institute of Child

Health, Dhaka Shishu Hospital

6, 7, 8, 9 Assistant Professor Bangladesh Institute of Child Health, Dhaka Shishu Hospital

\section{Correspondence}

Dr. Salahuddin Mahmud Assistant Professor, Dhaka Shishu (Children) Hospital, Dhaka Email: drsmbablu@gmail.com

\section{Abstract}

Background : Hepatitis A virus infection is endemic in many developing countries including Bangladesh. Children infected with Hepatitis-A virus typically have asymptomatic disease.

Objective : To observe the anti-HAV positivity in children \& to determine any relation between anti-HAV positivity \& socioeconomic condition.

Materials \& Methods : A cross sectional observational study was conducted at Bangabandhu Sheikh Mujib Medical University (BSMMU) Hospital \& Dhaka Shishu (Children) Hospital (DSH) from July 2008 to June 2009. Serum samples from 254 children aged between $1-15$ years were tested for antibody (IgM \& $\lg G)$ against hepatitis A virus (HAV) and detailed history was taken to find out the associated risk factors like residence, family income, source of drinking water, sanitation facility etc.

Results : Hepatitis A virus antibody was positive in 141 (55.5\%) of 254 children. Among all children anti-HAV positivity was significantly higher $(p=0.004)$ in lower income group $(64.8 \%)$ than higher income group (47.0\%). Anti-HAV positivity was significantly higher $(93.8 \%)$ in non-sanitary latrine users $\&$ in those who used unsafe drinking water. $(p=0.006)$

Conclusions : Majority of children were found sero-positive against HAV by 15 year of age. Anti-HAV positivity was significantly higher in lower socioeconomic group.

Key words : Anti-hepatitis A virus (HAV), HAV seroprevalence

\section{Introduction}

Hepatitis $A$ is an enterically transmitted viral disease world wide distributed. ${ }^{1}$ Acute viral hepatitis caused by HAV is an acute, self-limiting infection. ${ }^{2}$ Hepatitis $A$ virus infection is very common in early childhood and most of the infections are asymptomatic or mildly symptomatic. ${ }^{3}$ The incidence of HAV is higher in developing countries, the true incidence of hepatitis A is often underestimated because of under-reporting as a result of its widely asymptomatic and milder forms of infection.

Three epidemiologic patterns of endemicity (low, intermediate, and high), are seen worldwide. ${ }^{4}$ The countries with low endemicity include Japan, Singapore, Hongkong and Taiwan whereas those with moderate endemicity include Thailand, Malaysia and Sri Lanka. Countries with high endemicity for HAV infections include India, China, Nepal, Bangladesh, Pakistan, Myanmar and Philippines. ${ }^{5}$ In many developing countries of Africa, Asia and Latin America, most infections occur by 5 years of age where seroprevalence approach $90-100 \%$ by $10-15$ years of age. ${ }^{1}$ In Africa, Hendricks et al. ${ }^{6}$ showed anti-HAV positivity of $>90 \%$ among the 5-10 year age group among lower class black children.

In developing countries, low economic status, high crowding and inadequate water treatment contribute to a high endemicity pattern; more than $90 \%$ of the population has acquired natural immunity before 10 years of age, and often shows asymptomatic forms. In many developing countries like India, Pakistan, Nepal several sreo-prevalence studies have shown high rates of sero-positivity among children with subclinical infection. ${ }^{7}$ The present study was designed to identify HAV antibody (IgG \& IgM) among children of different age group attending two tertiary care hospitals of Bangladesh and to observe relation between anti-HAV positivity \& socioeconomic condition.

\section{Materials \& Methods}

A cross sectional observational study was conducted from July 2008 to June 2009 at blood collection centers of Bangabandhu Sheikh Mujib Medical University (BSMMU) Hospital \& Dhaka Shishu (Children) Hospital (DSH). A total of 254 children aged 1-15 years no previous history of jaundice or Hepatitis A vaccination were included in this study. The sample size was determined by the prevalence rates of neighburing countries with a similar socioeconomic condition (e.g., India \& Pakistan) as there are no previous data on HAV prevalence particularly children of Bangladesh. With prior written consent, clinical history and relevant data like age, sex, date of collection, residence, monthly income of individual family, source of drinking water, food habit $\&$ sanitation facility were recorded and $2 \mathrm{ml}$ of blood was collected from the study subjects.

A preformed semi structured data collecting form was used as a data collection instrument. Data were collected by researcher and analyzed by Statistical Package for social Science (SPSS) version 11.5 program. Data analysed by Chi-square $\left(\mathrm{x}^{2}\right)$ test. 


\section{Results}

Hepatitis A virus antibody (total) was found positive in 141 (55.5\%) of 254 children

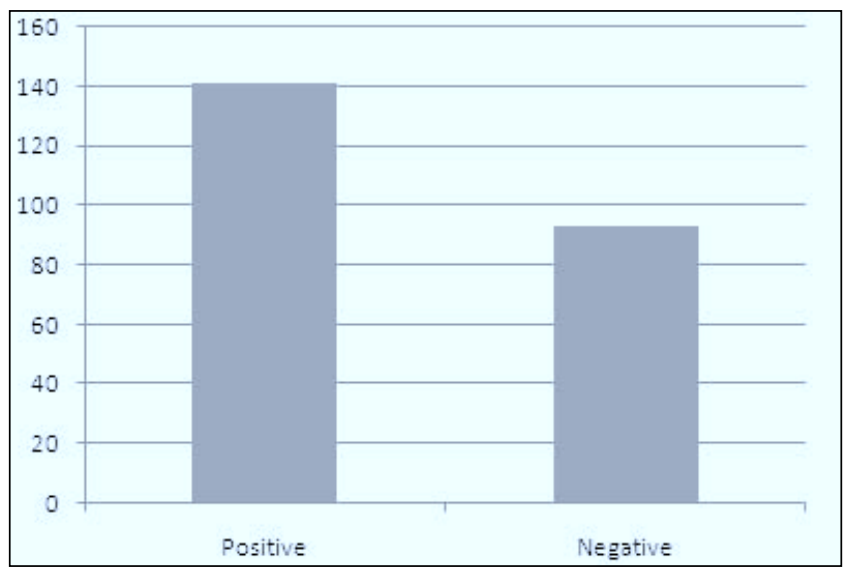

Fig: I Anti-HAV positivity among all children

Table I : Anti-HAV positivity with age

HAV antibody

$\begin{array}{llllll}\text { Age (yrs) } & \text { Total no } & \begin{array}{l}\text { Positive } \\ \text { No (\%) }\end{array} & \begin{array}{l}\text { Negative } \\ \text { No (\%) }\end{array} & \chi^{2} & \text { p-value } \\ 1-5 & 172 & \begin{array}{l}77(44.7) \\ 95(55.3)\end{array} & & \\ 5-10 & 55 & 39(70.9) & 16(29.1) & & \\ & & & & 4.970 & 0.026 \\ 10-15 & 27 & 25(92.6) & 2(7.4) & & \end{array}$

Anti-HAV of 1-5 year age group was found to be $44.7 \%$, it gradually increased to $70.9 \%$ in 5-10 year age group and finally to $92.6 \%$ in 10 15 year age group. Anti-HAV positivity of 5-10 year age group was significantly higher than that of $1-5$ year age group $(p=0.001)$ and antibody positivity of 10-15 year age group was significantly higher than that of $5-10$ year age group $(p=0.026)$. (Table I).

\section{Table II : Anti-HAV status between urban \& rural children}

$$
\text { HAV antibody }
$$

$\begin{array}{llllll}\text { Residence } & \text { Total no } & \text { Positive } & \text { Negative } & \chi^{2} & \text { p-value } \\ & & \text { No (\%) } & \text { No (\%) } & & \\ \text { Urban } & 161 & 90(55.9) & 71(44.1) & & \\ & & & & 0.027 & 0.870 \\ \text { Rural } & 93 & 51(54.8) & 42(45.2) & & \end{array}$

Ninety $(55.9 \%)$ children who live in urban area were found anti-HAV positive. On the other hand 51 (54.8\%) children from rural area were found anti-HAV positive. There is no significant difference between urban and rural children regarding HAV antibody positivity $(p=0.870)$. (Table 2)
Table III : Socioeconomic status of children with anti-HAV positivity HAV antibody

\begin{tabular}{|c|c|c|c|c|c|}
\hline \multirow{3}{*}{$\begin{array}{l}\text { Monthly } \\
\text { family } \\
\text { income (Tk) }\end{array}$} & \multirow{3}{*}{ Total no } & & \multirow{3}{*}{$\chi^{2}$} & \multirow{3}{*}{$p$-value } \\
\hline & & Positive & Negative & & \\
\hline & & No $(\%)$ & No $(\%)$ & & \\
\hline \multirow[t]{2}{*}{ Lower class $(<6000)$} & 122 & $79(64.8)$ & $43(35.2)$ & & \\
\hline & & & & 8.120 & 0.004 \\
\hline Higher class (>6000) & 132 & $62(47.0)$ & $70(53.0)$ & & \\
\hline
\end{tabular}

A significantly higher number $(64.8 \%)$ of children with positive HAV antibody came from lower socioeconomic class compared to that of children from higher class (47\%). $(p=0.004)$ (Table 3 )

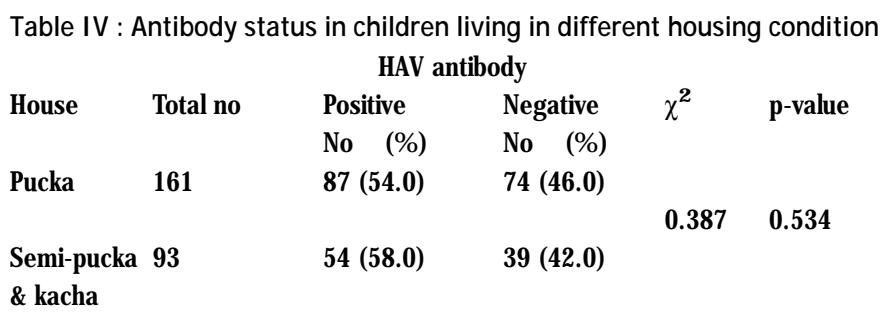

Eighty seven (54.0\%) children who lived in pucka house were found anti-HAV positive. On the other hand 54 (58.0\%) children who lived in semi-pucka $\&$ kacha house were found anti-HAV positive. Children who were living in the semi-pucka $\&$ kacha house were found to be anti-HAV positive more than that of children living in pucka house but result is not statistically significant ( $p=0.534)$. ( Table 4).

Table V : Antibody status of children with their sanitation facility

\begin{tabular}{|c|c|c|c|c|c|}
\hline \multirow{3}{*}{$\begin{array}{l}\text { Sanitation } \\
\text { facilities }\end{array}$} & \multicolumn{5}{|c|}{ HAV antibody } \\
\hline & Total no & Positive & Negative & $\chi^{2}$ & $p$-value \\
\hline & & No $(\%)$ & No $(\%)$ & & \\
\hline Sanitary latrine & 238 & $126(53.0)$ & $112(47.0)$ & & \\
\hline users & & & & 10.110 & 0.001 \\
\hline Non-sanitary & 16 & $15(93.8)$ & $1(6.2)$ & & \\
\hline latrine users & & & & 10.110 & 0.001 \\
\hline
\end{tabular}

Anti-HAV was found significantly $(p=0.001)$ higher among non-sanitary latrine users (93.8\%) than sanitary latrine users (53.0\%).( Table 5)

\section{Table VI : Antibody status of children with their source of drinking water}

\begin{tabular}{|c|c|c|c|c|c|}
\hline \multirow{3}{*}{$\begin{array}{l}\text { Source of drinking } \\
\text { water }\end{array}$} & \multicolumn{3}{|c|}{ HAV antibody } & \multirow[b]{2}{*}{$\chi^{2}$} & \multirow{3}{*}{ p-value } \\
\hline & Total no & Positive & Negative & & \\
\hline & & No $(\%)$ & No $\quad(\%)$ & & \\
\hline Safe water & 214 & 111 (51.6) & 104 (48.4) & & \\
\hline users & & & & 5.354 & 0.006 \\
\hline Unsafe water & 40 & $30(76.9)$ & $9(23.1)$ & & \\
\hline
\end{tabular}

Anti-HAV was found more (76.9\%) among unsafe drinking water user group than those of safe water users $(51.6 \%)$ and this difference is statistically significant $(p=0.006)$. (Table 6) 


\section{Discussion}

In the present study among 254 children the anti-HAV positive was $55.5 \%$. (141). Children at the age group of 1-5 years were found $44.7 \%$ positive Anti-HAV. It was found that sero-positivity increased with age, significant age groups were $5-10$ year $70.9 \% \quad(p=0.001)$ and $10-15$ year $92.6 \%(p=0.026)$. Similar results were also observed in other studies in Bangladesh by Ahmed et al. ${ }^{8}$ A study by Kamath et al. ${ }^{9}$ reported anti-HAV positivity of $61.6 \%$ in $5-10$ year age group and $97 \%$ in 11-15 year age group in Chennai, India. Agboatwalla et al. ${ }^{10} \&$ Sawayama et al. ${ }^{11}$ also reported similar results from Pakistan (94.1\% seropositive by the age of 5 years) and Nepal (91.1\% seropositive) respectively. Anti-HAV positivity was found $94.1 \%$ in $1-5$ year age group at Rawalpindi and 99\% in two rural villages in Nepal.

In the present study no significant difference was observed between urban (56\%) and rural (55\%) population regarding anti-HAV positivity. Similar result was also reported by Raharimanga et al. ${ }^{12}$ from Madagascar, Africa where no difference was observed between urban and rural population regarding anti-HAV positivity. But opposite picture was found $b$ Ahmed et al. ${ }^{8}$ showed that seropositivity of anti-HAV of rural subjects $(82 \%)$ were significantly higher than those of urban (73\%) population.

Significantly $(p<0.05)$ higher proportion of children with positive HAV antibody came from lower income group (64.8\%) compared to that of children with higher income group (47\%) in urban population. Saha et al. ${ }^{13}$ reported that seroprevalence of anti-HAV was lower $(49.8 \%)$ in higher income group than that of lower income group (96.5\%). Ahmed et al. $^{8}$ showed that anti-HAV was significantly higher in the lower income group $(79.2 \%)$ compared to that with higher income group (68.8\%). Socio-economic condition has some effect on anti-HAV positivity. Children living in the semi-pucka $\&$ kacha house were found to be anti-HAV positive in $58.0 \%$ cases which was nearly similar to children living in pucka house $54 \%(p>0.05)$. Ahmed et al. ${ }^{8}$ also reported the similar results. Overcrowding, poor hygienic and poor living conditions in kacha house may be the reasons of these differences.

In the current study, antibody was found significantly higher in non sanitary latrine users $93.7 \%$ than that of sanitary latrine users $53 \%$ $(p=0.001)$. Ahmed et al. ${ }^{8}$ reported that anti-HAV positivity depend on sanitation facility. Person to person transmission of HAV generally occurs by fecal-oral route. Common source outbreaks can occur from faecally contaminated food and water. General hygiene, especially in relation to sanitation, water supply and food preparation reflects the living standards and has major influence on HAV endemicity. For the same reason, anti-HAV positivity was found higher among unsafe (unboiled, filter \& ponds) water users (75\%) than that of safe (boiled \& tube well) water users (51.4\%). Occurrence of anti HAV antibody was significantly lower among users of tube well water than those who used unboiled supply water or common tap water.

\section{Conclusion}

In the studied children anti-HAV positivity was more than 45\% after 5 years of age and finally increased to more than $90 \%$ after 10 years of age. So, high proportion of children in the present study acquired HAV antibody early childhood and anti HAV positivity increased with increase in age. There is strong relation between anti-HAV positivity \& lower socioeconomic condition. Anti-HAV positivity was signicantly higher in low income group, non-sanitary latrine users and in those who use unsafe drinking water.

\section{Acknowledgement}

Prof. C. A. Kawser, PhD, Chairman of Pediatrics, BSMMU.

Prof. Samir K. Saha, PhD, Head, Dept. of Microbiology, BICH, DSH.

\section{References}

1. M. Z. Amina L. N. Siddiqueb, M. A. Satterc* and K. K. Biswasd; Increasing incidence of hepatitis A in Bangladesh, Bangladesh J. Sci. Ind. Res. 47(3), 309-312, 2012, Available online at www.banglajol.info

2. Feinstone SM, Gust ID. Hepatitis A virus. In: Richman DD, Whitley RJ, Hayden FG, editors. Clinical Virology. $2^{\text {nd }}$ ed. ASM press, Washington D.C; 2002. P 1019-32

3. Arora NK \& Mathur P. 'Epidemiological transition of hepatitis A in India: Issues for vaccination in developing countries'. Indian J ournal of Medical Research 2008; 128: 699704

4. Jacobson KH, Koopman JS, 2004. Declining hepatitis A seroprevalence: a global review and analysis. Epidemiol Infect 132: 1005-1022

5. Kar P. 'Is there a change in seroepidemiology of hepatitis A infection in India?' Indian J ournal of Medical Research 2006; 123: 727-29.

6. Hendrickx G, Herck KV, Vorsters A, Wiersma S, Shapiro C, Andrus JK et al. 'Has the time come to control hepatitis A globally? Matching prevention to the changing epidemiology'. Journal of Viral Hepatitis 2008; 15: 1-15

7. Chadha MS, Lole KS, Bora MH \& Arankalle, VA. 'Outbreaks of hepatitis A among children in Western India'. Transactions of the Royal Society of Tropical Medicine and Hygiene 2009; 1088: 1-6.

8. Ahmed M, Munshi SU, Nessa A, Ullah MS, Tabassum S \& Islam MN. 'High prevalence of hepatitis $A$ virus antibody among Bangladeshi children and young adults warrants preimmunization screening of antibody in HAV vaccination strategy'. Indian Journal of Medical Microbiology 2009; 27(1): 48-50.

9. Kamath SR, Sathiyasekaran M, Raja TE \& Sudha. 'Profile of viral hepatitis A in Chennai'. Indian Pediatrics 2009; 46: 642-3

10. Agboatwalla M, Isomura S, Miyake K, Yamashita T, Morishita T\& Akram DS.'Hepatitis A, B and C seroprevalence in Pakistan'. The Indian J ournal of Pediatrics 1994; 61: 545-9

11. Sawayama Y, Hayashi J, Ariyama I, Furusyo N, Kawasaki T, Kawasaki M et al. 'A ten year serological survey of hepatitis A, B and C viruses infections in Nepal'. Journal of Epidemiology 1999; 9(5): 350-54.

12. Raharimanga V, Carod JF, Ramarokoto CE, Chertien JB, Rakotomanana F, Talarmin A et al. 'Age specific seroprevalence of hepatitis A in Antananarivo (Madagascar)'. BMC Infectious Diseases 2008; 8(78): 1-6

13. Saha SK, Setarunnahar S, Shakur S, Hanif M, Habib MA, Dutta SK et al. 'Seroprevalence of hepatitis A infection by age group and socioeconomic status of Bangladesh'. $13^{\text {th }}$ International Congress on Infectious Diseases Abstracts, Poster Presentations 2008; 16(43): 101-02 